\title{
Improved understanding of Sodium hydroxide concentration role and kinetic model of cryolite reactive extraction in cathode Spent Pot Linings
}

\author{
Blaž Tropenauer ${ }^{1 *}$, Dušan Klinar², Janvit Golob ${ }^{3}$ \\ ${ }^{1}$ TALUM d.d. Kidričevo, Tovarniška cesta 10, 2325 Kidričevo, Slovenia \\ ${ }^{2}$ Scientific Research Centre BISTRA Ptuj, Slovenski trg 6, 2250 Ptuj, Slovenia \\ ${ }^{3}$ University of Ljubljana, Faculty of Chemistry and Chemical Technology, Večna pot 113, 1000 Ljubljana, Slovenia \\ "Corresponding author: e-mail: blaz.tropenauer@student.um.si
}

\begin{abstract}
Spent Pot Lining (SPL) cathode pot, waste from the aluminium smelting process needs detoxification from cyanides, washing out water-soluble salts and extraction of the cryolite $\left(\mathrm{Na}_{3} \mathrm{AlF}_{6}\right)$ decomposition products to be recycled. Revealed cryolite decomposition mechanism with $\mathrm{NaOH}$ opens possibilities to explore its critical role in the reactive extraction process. Common $\mathrm{Na}^{+}$ion from $\mathrm{NaOH}$ hinders the solubility of the product but also drives mass transfer to the reaction site. Reaction mass balance provides adequate liquid to solid ratio (L/S) and $\mathrm{NaOH}$ concentration range. A newly developed kinetic model based on Whitman film theory and $\mathrm{NaOH}$ mass flow enables prediction of the reaction time to decompose cryolite to a low enough level. Results show that the internal particle resistance to transport $\left(1 / \mathrm{k}_{\mathrm{s}}\right)$ is 19 times larger than the external $\left(1 / \mathrm{k}_{\mathrm{l}}\right)$ one and governs the whole process.
\end{abstract}

Keywords: Spent pot lining; $\mathrm{NaOH}$ concentration role; cryolite decomposition; reaction mechanism; kinetic model.

\section{INTRODUCTION}

Hundred thirty years passed since Hall-Héroult electrolytic reduction and smelting process becomes a basic industrial process for the reduction of alumina $\left(\mathrm{Al}_{2} \mathrm{O}_{3}\right)$. Nevertheless, the process achieved a significant level regarding energy efficiency and waste product recycling like anodes. Only cathode pot remains systemically unrecycled in many of the production locations around the world, although some technologies for processing exist ${ }^{1,2}$.

Waste is known as Spent Pot Lining (SPL) and derives from each electrolytic cell, or more precisely from the material of the cathode electrode or pot ${ }^{3-6}$.

Current European trends regarding hazardous waste streams demand a zero-waste concept and follow effort in aluminium production to complete recovery of SPL streams in a sustainable solution. Besides a waste burden, the material also represents an opportunity to harvest either its energy and/or valuable material content ${ }^{7}$.

Residue appears as SPL and is, after mechanical deterioration, sorted to the first cut (FC, mostly carbon) and second cut (SC, mostly chamotte) material.

Since disposal is placed on the base of the wastes hierarchy, some new solutions for waste materials treatment need to be provided. The concept of circular and low carbon economy directs toward the use of materials in the local/regional application chains ${ }^{8}$.

The study follows a new, concept of the SPL treatment process. All undesirable substances like $\mathrm{NaF}$ and cryolite should be extracted out, and toxic components in the form of cyanides disintegrated. Nontoxic and unreachable product almost without sodium and fluorine can be used in a local circular economy. The new concept introduces no new species in the reaction system, low-temperature processing, low concentrations and no waste streams.

Improved understanding of the $\mathrm{NaOH}$ role in a reaction mechanism of the cryolite decomposition and the role of ligands gave, for the first time, the possibility to find the influence of the concentration on a whole process and most significant resistance in the mass transport and chemical reaction chain. Solubility constraint of fluorine ions and common ion effect is theoretically and experimentally determined. Experimental results confirm that the reactive extraction process governs the solubility of its products and internal diffusion resistance inside material particles.

\section{MATERIALS AND METHODS}

Both, FC and SC components are declared as hazardous toxic materials (HTM) due to: (i) water leachable fluoride and cyanide salts, (ii) corrosiveness - exhibiting high $\mathrm{pH}(12)$ due to content of metallic oxides $\left(\mathrm{Na}_{2} \mathrm{O}\right)$ and (iii) reaction of carbides, nitrides and $\mathrm{Al}$ metal with water and alkaline to form toxic and explosive gases like methane, ammonia and hydrogen (approx. $0.2 \mathrm{l} / \mathrm{kg}$ of SPL). Typical chemical composition of average SPL, FC and SC, are summarised in Table 1.

Table 1. Approximate mass composition of whole SPL and mechanical separated first cut (FC); compositions usually variate more than $\pm 10 \%$

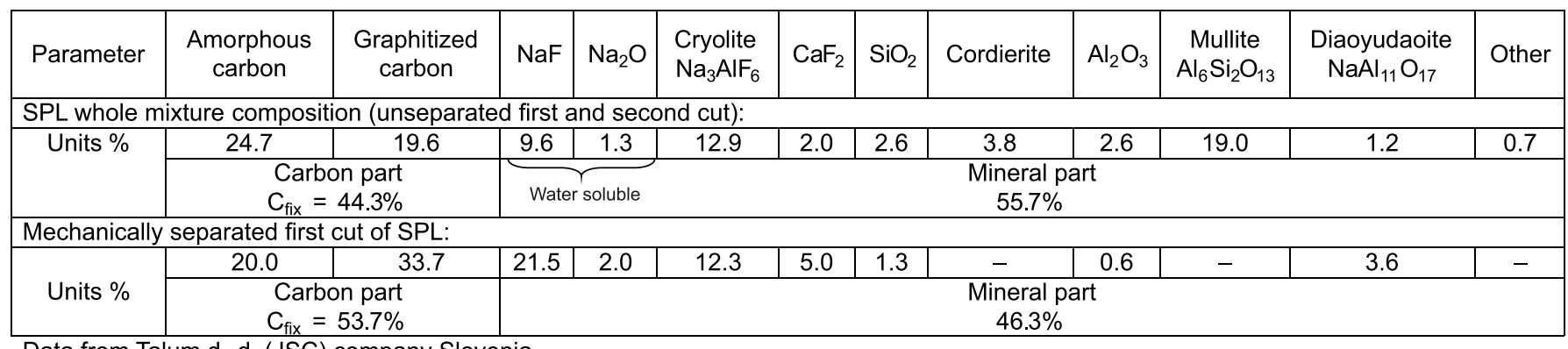

Data from Talum d. d. (JSC) company Slovenia 
It is necessary to separate both parts at the beginning during mechanical demolition.

\section{Preliminary investigations}

Separation of the salts impregnated in carbon and chamotte structure becomes a primary concern while containing most sodium and fluorine salts. Removal of the about $20 \%$ of $\mathrm{NaF}$, as a very well solvable strong electrolyte, looks to be the right task for water extraction in the first stage. As SPL contains $1-2 \%$ of $\mathrm{Na}_{2} \mathrm{~F}$ immediate reaction with water gives sodium hydroxide, which raises the $\mathrm{pH}$ to more than 12 . After NaF removal, cryolite remains as the next massive component in the SPL material with an average value of $13 \%$ of the whole sample. With a very low solubility product constant $-\mathrm{K}_{\mathrm{sp}}$ cryolite, as an almost insoluble component, must be chemically decomposed first to get water-soluble products. Some attempts propose disintegration at higher temperatures $^{\mathbf{9 - 1 1}}$. The basic concept of industrial application directs experiments toward the low-temperature reactive extraction process with the implementation of no new ionic species into the system. Within the proposed concept, a decomposition of cryolite becomes a central concern in the study. According to the literature, different caustic and acid reactants can also be used for this purpose. To obtain $\mathrm{H}_{2} \mathrm{SiF}_{6}$ and $\mathrm{AlF}_{3}$ as the desired component in the electrolytic process Schönfelder ${ }^{\mathbf{1 2}}$ chose $\mathrm{H}_{2} \mathrm{SO}_{4}$ as a solvent. Zhao ${ }^{13}$ suggested the same solvent for $\mathrm{HF}$ production. Shi Z. ${ }^{\mathbf{1 4}}$ used on the other hand $2.5 \mathrm{M} \mathrm{NaOH}$ solution with $\mathrm{L} / \mathrm{S}$ ratio (Liquid to Solid ratio expressed in $\mathrm{ml} / \mathrm{g}$ and declared as L/S) of 6 to separate cryolite from SPL while Kasireddy ${ }^{\mathbf{1 5}}$ used 0.5 to $1.25 \mathrm{M} \mathrm{NaOH}$ solution with the preferred L/S ratio of 6 .

As the introduction of new ions into the system is not favorable, especially sulphur-based products in the extract, a caustic disintegration of the cryolite takes central attention in the research.

Sodium Hydroxide reacts with cryolite according to a well-known reaction presented with Equation (1) however, reaction steps and mechanism, essential for the design of the process, remain unpublished. This way, preliminary investigations start with batch laboratory tests of FC samples water leaching and searching for a mechanism of cryolite decomposition with sodium hydroxide.

$$
\begin{aligned}
& \mathrm{Na}_{3}\left[\mathrm{AlF}_{6}\right](\mathrm{s})+4 \mathrm{NaOH}(a q) \rightarrow 6 \mathrm{NaF}(a q .) \\
& +\mathrm{Na}\left[\mathrm{Al}(\mathrm{OH})_{4}\right](a q)
\end{aligned}
$$

Sodium hydroxide concentration, reaction time and L/S ratio are the main parameters under consideration as they influence most on the results of decomposition and extraction $^{\mathbf{1 6}}$ of the cryolite in Equation (2). The use of pure cryolite $(97.5 \%)$ eliminates some possible influence of other components on the decomposition mechanism and simplifies mass transfer picture at the surface of the particle. Revealed reaction and mass transport mechanism in this preliminary investigation stage serves as the main model in the central experimental part on origin material as FC samples present.

\section{Reaction mechanism of cryolite decomposition}

Cryolite, with its very low solubility of $0.04 \%$ at $20^{\circ} \mathrm{C}^{17}$, consists of a complex structure in its crystal. Complex anion is formed with fluorine as a ligand arranged in the octahedral structure around a central ion. Ligands contribute electrons to an empty d orbital of the central atom to form a complex anion. As a counterbalance to the negative charge, the compound of the cryolite contains three cations. Decomposition reactions and dissolution, take place during the reactive extraction process, start with cryolite dissociation in water.

To increase the decomposition rate of the cryolite according to Le'Chatelier principle, some products need to be eliminated from the reaction plan. In the first step, toward shifting the reaction to the right, complex anion $\left[\mathrm{AlF}_{6}\right]^{3-}$ reacts and disintegrates in hydroxide anion rich solution at high $\mathrm{pH}(8-12)$ to $\mathrm{Al}(\mathrm{OH})_{4}{ }^{-}$anion or $\mathrm{AlF}_{\mathrm{x}}(\mathrm{OH})^{-}{ }_{3-\mathrm{x}}$ anions ${ }^{\mathbf{1 6}}$ depending on $\mathrm{pH}$ and $\mathrm{Al} / \mathrm{F}$ ratio in the solution. At low $\mathrm{F}^{-}$concentrations and high $\mathrm{pH}$ values $^{18} \mathrm{Al}(\mathrm{OH})_{4}^{-}$anion exists, a second step in the reaction of cryolite decomposition can be written as follows by Equation (2).

$$
\left[\mathrm{AlF}_{6}\right]^{3-}+4[\mathrm{OH}]^{-} \rightarrow\left[\mathrm{Al}(\mathrm{OH})_{4}\right]^{-}+6 \mathrm{~F}^{-}
$$

The formation of $\left[\mathrm{Al}(\mathrm{OH})_{4}\right]^{-}$is confirmed by the stability constant of the $\mathrm{Al}-\mathrm{OH}$ complexes for this ion $(\log \mathrm{K}=33)$. Concerning $\mathrm{Al}^{3+}-\mathrm{F}^{-}-\mathrm{OH}^{-}$the system presented by Sjoeberg $^{18}$ indicates the existence of considered species start to appear in the $\mathrm{pH}$ range from 8 to 9 and above. The $\mathrm{pH}$ of 10 in the samples assures its presence.

As $\mathrm{OH}^{-}$is a stronger base than $\mathrm{F}^{-}$, metal ions like $\mathrm{Al}^{3+}$ act as strong acids and bind preferentially to hydroxide, therefore, increase the stability of the complex. Also, as can be seen from the spectrochemical series, $\left(\mathrm{I}^{-}<\right.$ $\mathrm{Br}^{-}<\mathrm{Cl}^{-}<\mathrm{F}^{-}<\mathrm{OH}^{-}$) the crystal field splitting energy $\left(\Delta_{0}\right)$ of $\mathrm{OH}^{-}$is larger than of a $\mathrm{F}^{-}$ion. Greater $\Delta_{0}$ contributes to shorter metal-ligand distance as ligands are more strongly attracted to the metal ion and therefore, increased stability of the complex ${ }^{19}$.

Finally, as a summary, both reaction steps can be understood as one continuous reaction presented in Equation (1).

Large amounts of sodium and fluorine ions appear as a product, and a lot of sodium hydroxide existing as a reactant seems to be the fundamental characteristic of the whole reaction. Reactions in the presented mechanism are of the ionic type and very fast or almost instantaneous. Consequently, other factors than pure reaction kinetics influence the decomposition reaction rate; in the following part, its analysis becomes the main focus.

\section{Factors affecting the decomposition reaction rate}

Firstly, a large amount of appearing sodium ion suggests that the thermodynamic factors like solubility of fluoride ions in sodium hydroxide solution, as the central reactant, play an important role. Phase equilibria governed by Gibbs phase rule and law of mass action help to understand solubility limitation in the complex solution. Phase rule $\mathrm{F}+\mathrm{P}=\mathrm{C}+2$ gives $\mathrm{P}=2$ while only two Phases $(\mathrm{P}=$ number of phases $)$ can exist at equilibrium. Three Components $\left(\mathrm{C}: \mathrm{H}_{2} \mathrm{O}, \mathrm{NaF}\right.$ and $\mathrm{NaOH}$ ) give three degrees of Freedom (F) of the system, with constant Pressure and Temperature. The selected concentration of $\mathrm{NaOH}$ fixes the solubility of the second component 
$\mathrm{NaF}$. Variation of common ion enables calculation of the $\mathrm{NaF}$ solubility dependence on $\mathrm{NaOH}$ concentration.

Secondly, a fulfilled mass balance assures enough sodium hydroxide to disintegrate complete cryolite in the solids. The minimum ratio of $\mathrm{L} / \mathrm{S}$ (for each concentration) provides enough sodium hydroxide for this purpose. Oppositely, limiting solubility of $\mathrm{NaF}$ determines the maximum $\mathrm{L} / \mathrm{S}$ ratio to assure solubility not to be exceeded.

Thirdly, mass transfer factors contribute mainly to cryolite decomposition reaction resistance of a consecutive reaction path. With combining the first Fick's law and the Whitman film theory, the decomposition kinetics can be modelled and tested in the experimental configuration.

\section{Solution thermodynamics}

The common sodium ion does not hinder the cryolite decomposition rate directly but affects solubility due to an instantaneous ionic reaction in the Equation (2). In the heterogeneous system, diffusion of the products and reactants limits the reaction rate. In a consecutive system, the slowest process determines the rate of the whole process. The low solubility of $\mathrm{NaF}$, as a reaction product, limits the diffusion process mostly ${ }^{16}$ and limits the entire process. Effect of the common ion in the system under consideration was proposed but not quantified mathematically yet. Such an approach is improved by the implementation of the law of mass action to quantify the solubility equilibrium.

The common $\mathrm{Na}^{+}$ion from cryolite ( 3 ions) and mostly $\mathrm{NaOH}$ (4 ions) obstruct the $\mathrm{NaF}$ solubility. In water, the $\mathrm{NaF}$ solubility at $20^{\circ} \mathrm{C}$ is $40.6 \mathrm{~g} / \mathrm{L}(0.967 \mathrm{M})^{20}$. The $\mathrm{NaF}$ solubility drops from $0.967 \mathrm{M}$ in water to $0.6 \mathrm{M}$ in $1 \mathrm{M}$ $\mathrm{NaOH}$ solution. The solubility product $-\mathrm{K}_{\mathrm{sp}}$ enables the approximation of the $\mathrm{NaF}$ solubility and its dependence on $\mathrm{NaOH}$ concentration. This approximation does not consider the ionic strength of the solution and related ionic activity coefficients. $\mathrm{NaF}$ solubility $-\mathrm{S}$ at various $\mathrm{NaOH}$ concentrations $-\mathrm{n}$ gives:

$K_{s p}=\left[N a^{+}\right] \cdot\left[F^{-}\right]=[S+n] \cdot[S]=S^{2}+n \cdot S$

After the arrangement, the solution of the equation gives the dependence of $\mathrm{NaF}$ solubility on $\mathrm{NaOH}$ concentration presented in Fig. 5. Calculated results, compared with the experimental results of different authors ${ }^{20-22}$, give a reasonably good fit within the uncertainty range of the measured data. Calculated and the Selvaraj results ${ }^{21}$ have the largest negative slope of solubility within a range from 0 to $1 \mathrm{M} \mathrm{NaOH}$ concentrations and consequently determine the concentration window for the reactive extraction process.

\section{Mass balance and $L / S$ ratio}

The Equation (1) gives mass balance for the decomposition and dissolution of the cryolite. L/S ratio was taken as a measure of mass balance to simplify batch experiments design, used rather widely ${ }^{14}$. The minimum $\mathrm{L} / \mathrm{S}$ ratio provides only the framework of the $\mathrm{NaOH}$ mass balance but does not avoid or take into account solubility limit calculated with Equation (3). L/S calculations are always based on (pure) cryolite content in the material processed. Applying (selected) $1 \mathrm{M}$ solution $\mathrm{NaOH}$ gives $(\mathrm{L} / \mathrm{S})_{\min }$ of $19 \mathrm{ml} / \mathrm{g}$. Calculated $\mathrm{NaF}$ concentration at $1.5 \mathrm{M} \mathrm{NaOH}$ exceeds its solubility limit of $0.57 \mathrm{M}$ as saturation concentration. To operate below the saturation curve calculated by Equation (3), a larger L/S ratio than a minimal needs to be applied. Calculations in the broader range of $\mathrm{NaOH}$ concentrations $(0.2$ to $1.5 \mathrm{M})$ directed to the optimal L/S ratio from 50 to $100 \mathrm{ml} / \mathrm{g}$. Concentrations of $\mathrm{NaOH}$ in a range of smaller than 1 $\mathrm{M}$ and proposed optimal L/S ratios give the frame for experimental arrangements and also for the evaluation of the reactive extraction process.

\section{Process constraints}

Before the presentation of work on process kinetics, some significant constraints of the process should to be pointed out:

- The solubility of the cryolite decomposition product - NaF should be kept reasonably below its saturation curve calculated with Equation (3).

- The average reactant $\mathrm{NaOH}$ concentration difference from the process start to its end should be high as possible.

- Consequently, a high L/S or substantially larger $\mathrm{L} / \mathrm{S}$ ratio than minimal should be applied to assure the second constraint $-\mathrm{NaOH}$ average concentration high.

The limited solubility of the NaF, as the largest mass part of decomposition reaction in the reactant solution, can hinder by common ion effect the course of the reaction itself. A second product $\left[\mathrm{Al}(\mathrm{OH})_{4}\right] \mathrm{Na}$ is not limited by its solubility. With the choice of optimal reactant concentration and adequate large enough $\mathrm{L} / \mathrm{S}$ ratio, all constraints can be avoided.

\section{Mass transfer and decomposition kinetics}

Kinetics of the cryolite decomposition inside the amorphous and partly graphitized carbon - coke can be complicated as different types of resistances are possible. A process kinetics modeled on pure cryolite particles can give an elementary reaction field picture, without the influence of other factors. As ionic reactions are very fast, only transport of reactant $-\mathrm{NaOH}$ to reaction site and products as $\mathrm{NaF}$ to the solution and its solubility determines the process kinetics. The kinetics of the process depends on the reactant concentration, driving mass transfer process around cryolite particles. Combining first Fick's law governing diffusion around particles with Whitman's film theory a modified equation for the mass transfer through the stagnant film $-\mathrm{J}$ in $\left(\mathrm{kg} / \mathrm{m}^{2} \cdot \mathrm{s}\right)$ can be derived by Equation (4). A mass transfer coefficient for liquid in $\mathrm{k}_{\mathrm{l}}(\mathrm{m} / \mathrm{s})$ is derived from an approximation of differential with concentration gradient $-\Delta \mathrm{C}$ divided by a stagnant film around particles and its thickness $\delta_{\mathrm{f}}(\mathrm{m})$ - a left side of the Equation (4). In the same equation, a $\mathrm{NaOH}$ mass flow to particles was equalized with cryolite decomposition rate - a left side of the Equation (5). In further transformation, surface (A) replaces all cryolite particles surface calculated as spherical particles with density $\left(\rho_{\mathrm{p}}\right)$ and radius $\left(\mathrm{r}_{\mathrm{p}}\right)$. Following integration between the mass of cryolite particles ( $\mathrm{m}_{0}$ to $\mathrm{m}$ ) and its decomposition time ( 0 to $t$ ), the equation for cryolite particles decomposition becomes Equation (6). 
$J=-D \frac{d C}{d X} \Rightarrow \frac{d C}{d X} \approx \frac{\Delta C}{\delta_{f}} \Rightarrow k_{l}=\frac{D}{\delta_{f}} \Rightarrow J=k_{l} \cdot \Delta C$

$-\frac{d m}{d t}=k_{l} \cdot A \cdot \Delta C \Rightarrow A=n_{p} \cdot A_{p}=\frac{3 m}{\rho_{p} r_{p}}$

$\Rightarrow>\frac{1}{m} \cdot d m=-\frac{3 k_{l} \Delta C}{\rho_{p} r_{p}} \cdot d t$

$\ln \frac{m}{m_{0}}=-K \cdot t \quad$ where $K=\frac{3 k_{l} \Delta C}{\rho_{p} r_{p}}$

Equation (6) represents a primary tool in the analyses of the decomposition experiments with the cryolite in the pure form and as well as coke particles - FC material (with cryolite inside the matrix) to assess overall mass transfer coefficient. The equation also supports calculation of cryolite decomposition mass balance.

\section{Experiments}

To obtain the dependence of decomposition reaction time $\mathrm{NaOH}$ on concentration and $\mathrm{L} / \mathrm{S}$ ratio experiments were performed with pure cryolite and FC with different particles sizes and mixing conditions.

Experiments were performed in two series. The first pure cryolite preliminary series use to confirm its decomposition reaction mechanism in the pure system. In the second series, tests were performed on the real samples of the FC material from the industrial plant. Experiments with FC samples upgrade results to engineering process parameters needed to determine the reactive extraction process.

All experiments were conducted in a batch mixing reactor at $20^{\circ} \mathrm{C}$ to confirm the possibilities of the extraction process without additional heat consumption. Mass balance calculated as $\mathrm{L} / \mathrm{S}$ ratio was applied with the access of reactant $-\mathrm{NaOH}$, described above. Selected mixing times from few minutes to several hours cover the whole range of cryolite decomposition. The reactive leaching procedure was performed in a $400 \mathrm{ml}$ low beaker $\left(\mathrm{d}_{\text {in }}=78 \mathrm{~mm}\right)$ with $50 \mathrm{~mm}$ long magnetic stirrer at a speed of $500 \mathrm{rpm}$ and samples mass in a range of $20 \mathrm{~g}$. Remaining samples were vacuum filtered on a blue ribbon filter paper, dried for $24 \mathrm{~h}$ at $120^{\circ} \mathrm{C}$ and weighed.

The size of FC sample particles largely depends on the application in metallurgical smelting processes, which favour larger particles in a range from 1 to $3 \mathrm{~mm}$ than others. For laboratory experiments, smaller particles up to $100 \mu \mathrm{m}$ are applied. The grinding process needs special attention due to the sticky nature of FC material, which could cause problems ${ }^{23}$.

To avoid the common ion effect and consequently, $\mathrm{NaF}$ limited solubility samples were first extracted with pure water and wet residues later subjected to reactive alkaline treatment to decompose cryolite and raise the carbon content in the samples to a high level.

Pure Cryolite decomposition tests

Cryolite $\left(\mathrm{Na}_{3} \mathrm{AlF}_{6}\right)$ salt of $97.5 \%$ purity was grinded to granulation in a range from 10 to $60 \mu \mathrm{m}$ with $\mathrm{d}_{50}=50 \mu \mathrm{m}$. The series of experiments were performed at $\mathrm{L} / \mathrm{S}$ ratio from $50 \mathrm{ml} / \mathrm{g}$ with $1 \mathrm{M} \mathrm{NaOH}$ to $105 \mathrm{ml} / \mathrm{g}$ with $0.2 \mathrm{M} \mathrm{NaOH}$ and stirring times of $20,30,60,180$ and $300 \mathrm{~min}$.

\section{First cut - FC experiments}

Samples were taken from Talum company Al smelter in Slovenia from the electrolysis cell after 6.5 years of operation. Large samples in the form of $20-40 \mathrm{~cm}$ wide chunks were taken from the dismantled spent cathode pot. The FC samples were ground in the Retsch MM 400 device to prepare a finer sample with $\mathrm{d}_{50}=30 \mu \mathrm{m}$. The samples contain merely carbon and compounds like $\mathrm{NaF}$, cryolite, $\mathrm{SiO}_{2}$, sodium aluminate, $\mathrm{CaF}_{2}$ and others according to the average composition presented in Table 1.

All the samples were initially extracted with pure water to separate about $23 \%$ of the soluble fraction - mainly $\mathrm{NaF}$ as salt. Samples were mixed in a batch reactor arrangement as described above, initially for a period of $1 \mathrm{~h}$ and repeated to extract more than $95 \%$ of soluble substances. About $12 \%$ of water-insoluble cryolite remained inside the carbon matrix consists of approx. $60 \%$ of graphitized and $40 \%$ of amorphous carbon. Samples were filtered and dried as described above, before exposure to $\mathrm{NaOH}$ reactive extraction.

Fixed-carbon content $\left(\mathrm{C}_{\text {fix }}\right)$ was analyzed in a Mettler Toledo TGA/DSC 1 analyzer by STARe software. After reactive extraction samples were two times washed with water to avoid contamination, filtered and dried before sent to analysis. $X$-ray fluorescence $(X R F)$ was used for elementary quantitative analysis and measured on Thermo ARL Advant'X XRF with copper tube operated at $50 \mathrm{kV}$ and $60 \mathrm{~mA}$. X-ray diffraction (XRD) was used for solid crystal phase identification using a Panalytical Cubix3 X-Ray Diffractometer equipped with an X'Celerator detector. The copper tube operated at $50 \mathrm{kV}$ and $40 \mathrm{~mA}$. Qualitative and quantitative analysis with the Rietveld method was used to obtain the mass fractions of the compounds analyzed by X'Pert PRO x-ray powder diffractometer with $\mathrm{Cu}-\mathrm{K} \alpha 1$ radiation in the 2Theta range from 5 to $90^{\circ}$ and with a step of $0.017^{\circ}$, $0.7 \mathrm{~s} / \mathrm{step}$ - time per step and 59 min scan time.

The alkali leaching experiments were conducted with two limited concentrations of $\mathrm{NaOH} 0.3$ and $1 \mathrm{M}$ and corresponding $\mathrm{L} / \mathrm{S}$ ratio of 21 and $15 \mathrm{ml} / \mathrm{g}$ at stirring times of 9, 30, 60 and $180 \mathrm{~min}$.

\section{RESULTS AND DISCUSSION}

\section{Experiments with pure cryolite}

First series of the experiments conducted at different concentrations of $\mathrm{NaOH}$ solution, at $\mathrm{L} / \mathrm{S} 50 \mathrm{ml} / \mathrm{g}$ and reaction times up to 5 hours where more than $92 \%$ of the cryolite was decomposed and dissolved. The results of the remaining cryolite mass indicate the process transition point at 3 hours, where decomposition slows down to a substantially low rate.

Diminishing of the remaining cryolite after 3 hours of reaction with $\mathrm{NaOH}$ in the whole testing range is technically negligible slow and cannot be solved in the same contacting system. Solutions can be twofold, change mixing contacting system to counter current or leaves a small amount of the cryolite undecomposed.

The significance of the NaF solubility potential, measured as the percentage of actual concentration below the saturation point is presented in Fig. 1. Results suggest 
a)

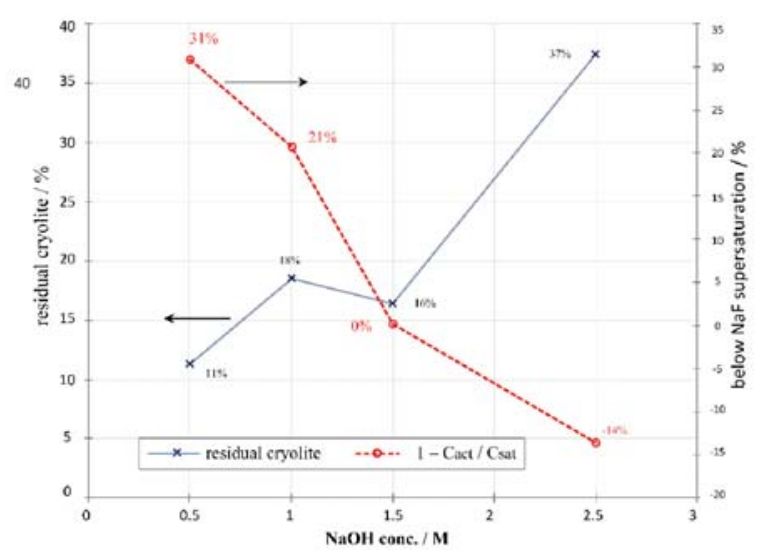

b)

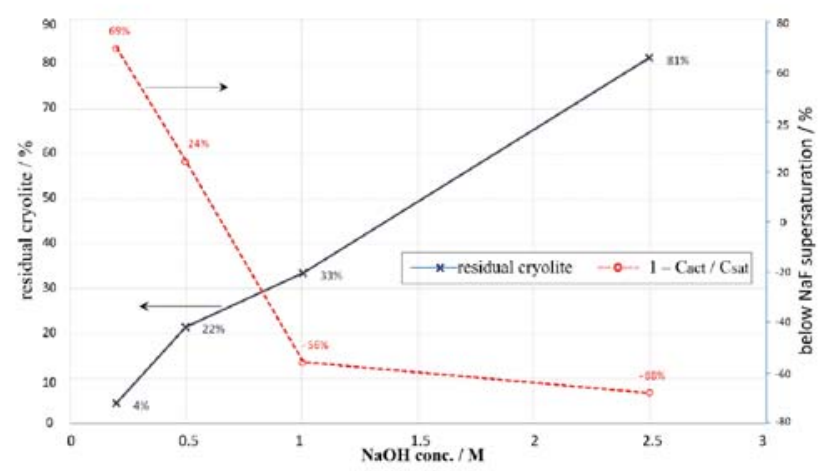

Figure 1. Residual Cryolite in \% in different $\mathrm{NaOH}$ solution and: a.) $\mathrm{L} / \mathrm{S}=50 \mathrm{ml} / \mathrm{g}$ - mean 3.15 times $(L / S)_{\min }$ on average and $60 \mathrm{~min}, \mathrm{~b}$.) L/S taken 1.13 times $(L / S)$ $\min$ and reaction time $180 \mathrm{~min}$

inverse proportional relation of a difference between the actual and saturated concentration of $\mathrm{NaF}$ at applied reactant concentration. The same relation can be seen at three time's larger reaction times $1: 3$ and L/S ratio 3:1. At these conditions, the level of cryolite decomposition is higher even at three time's shorter reaction time what confirms the importance of L/S ratio. High level of $\mathrm{L} / \mathrm{S}$ ratio above $(\mathrm{L} / \mathrm{S})_{\min }$ assures high average concentration potential of the $\mathrm{NaOH}$ even at the end of the reaction and provides enough space for reaction products like NaF.

According to results, a series of close to optimal experiments were performed in a lower range of concentration - $0.3 \mathrm{M} \mathrm{NaOH}$ and $\mathrm{L} / \mathrm{S}$ of $90 \mathrm{ml} / \mathrm{g} 1.43$ times $(\mathrm{L} / \mathrm{S})_{\min }$.

Analysis of the process kinetics, according to Equation (6) presented in Fig. 2 gives proportional factor $\mathrm{K}$ as $5.94 \cdot 10^{-4} \cdot \mathrm{s}^{-1}$. With given data for cryolite particles as $\rho_{\mathrm{p}}=3 \cdot 10^{3} \mathrm{~kg} / \mathrm{m}^{3}, \mathrm{r}_{\mathrm{p}}=2.5 \cdot 10^{-5} \mathrm{~m}$ and $\Delta \mathrm{C}_{\mathrm{av}}=9.2$ $\mathrm{kg} / \mathrm{m}^{3}$ (in a range from $0.3 \mathrm{M}$ to $0.105 \mathrm{M}$ at the end) a mass transfer coefficient $\mathrm{k}_{1}$ was calculated as $1.61 \cdot 10^{-6}$ $\mathrm{m} / \mathrm{s}$. The calculated value of $\mathrm{k}_{\mathrm{l}}$ is in confirmation with published values for ionic species in water. The result enables discrimination among resistance in the liquid film around the particle and resistance in the pores inside particles at experiments with the first cut - FC material.

\section{Decomposition of the cryolite in a first cut sample}

First cut material (FC) with the average composition presented in Table 1 and $\mathrm{d} 50=30 \mu \mathrm{m}$ granulation was initially extracted with water to eliminate originally pre-

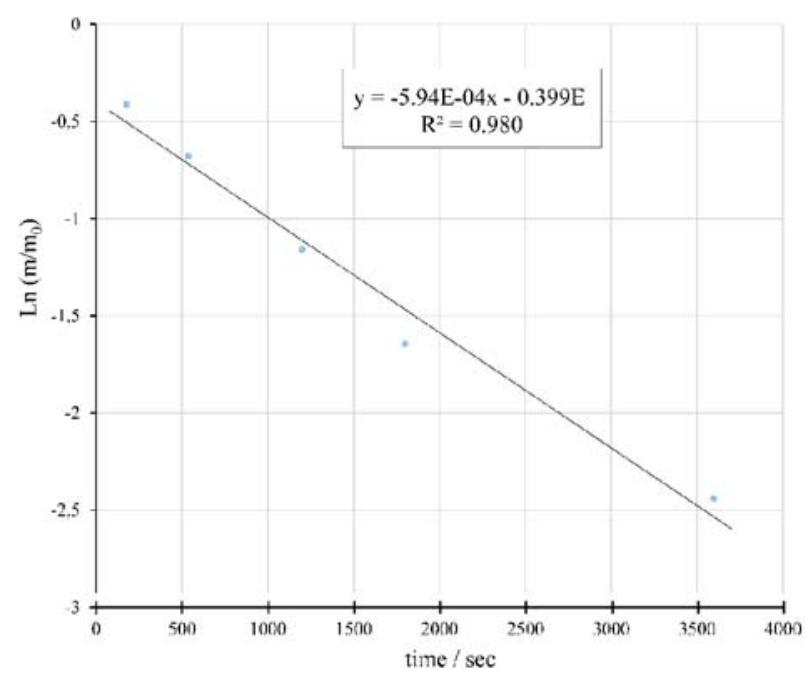

Figure 2. Decomposition kinetics of pure cryolite sample calculated by Equation (6) in $0.3 \mathrm{M} \mathrm{NaOH}$ solution and $\mathrm{L} / \mathrm{S}$ of $90 \mathrm{ml} / \mathrm{g} 1.43$ times $(L / S)_{\min }$

sented NaF. Elimination of the originated $\mathrm{NaF}$ avoids hindering the alkali reaction of cryolite decomposition and extraction from the FC carbon matrix.

Initially, water leached $\mathrm{FC}$ samples were reacted with $1 \mathrm{M} \mathrm{NaOH}$ solution at $\mathrm{L} / \mathrm{S}$ of $15 \mathrm{ml} / \mathrm{g}\left(3.4\right.$ times $(\mathrm{L} / \mathrm{S})_{\min }$ - calculated on cryolite content) and $3 \mathrm{~h}$ mixing time. An XRD diffractogram analysis presented in Fig. 3 indicates the disappearance of cryolite ${ }^{24}$. Quantitative analysis acc. to Rietveld gives $5.1 \%$ of cryolite at the end from $23.1 \%$ at the beginning, which means $78 \%$ removal of the cryolite.

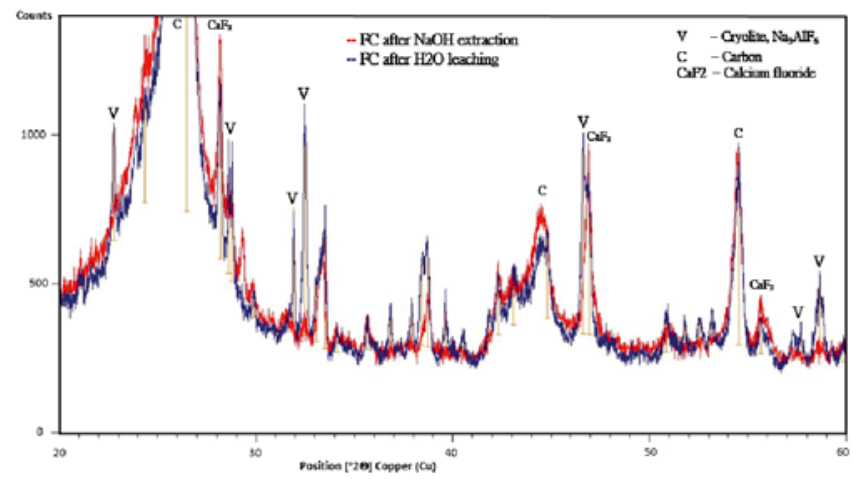

Figure 3. Diffractograms of an effective cryolite decomposition: pixels (V): 32 and 32.5; 57.8 and 58.7 have a lower value on the red line after alkali leaching step. Crystallographic data from ICCD: carbon 00-008-415, $\mathrm{CaF}_{2}$ 03-065-0535, cryolite 00-025-0772

Sample of FC contains initially $72.2 \%$ of carbon and rises to $79.6 \%$ after $\mathrm{NaOH}$ reaction, insoluble components like $\mathrm{CaF}_{2}-7.4 \%$ and diaoyudaoite $-\mathrm{NaAl}_{11} \mathrm{O}_{17}$ $-3.9 \%$ remains.

Next FC leaching experiment at the same conditions as with pure cryolite on Fig. 2 with $0.3 \mathrm{M} \mathrm{NaOH}$ and $\mathrm{L} / \mathrm{S}$ of $21 \mathrm{ml} / \mathrm{g}$ (based on cryolite content) 1.43 times $(\mathrm{L} / \mathrm{S})_{\min }$ indicates a steady reduction of cryolite in the FC sample with time. XRD quantitative analysis from $3 \mathrm{~h}$ comparable mixing time gives $7.4 \%$ of cryolite at the end from $23.1 \%$ at the beginning; $68 \%$ of cryolite was removed. Initial carbon content rises from $72.2 \%$ to $83 \%$, a larger rise of $\mathrm{C}_{\mathrm{fix}}$ in the second experiment can 
be related to larger $\mathrm{L} / \mathrm{S}$ ratio of $21 \mathrm{ml} / \mathrm{g}$ comparing to $15 \mathrm{ml} / \mathrm{g}$. More water probably dissolves some remained water leachable components from particles.

Process kinetics analysis with Equation (6) from Fig. 4 gives proportional factor $\mathrm{K}$ as $6.35 \cdot 10^{-5} \cdot \mathrm{s}^{-1}$. A decade smaller number suggests larger overall resistance of the species transport into the graphitized coke particles and products backward to the solution. With the data for graphitized coke: $\rho=2.2 \cdot 10^{3} \mathrm{~kg} / \mathrm{m}^{3}, \mathrm{r}_{\mathrm{p}}=1.5 \cdot 10^{-5}$ $\mathrm{m}$ and $\Delta \mathrm{C}_{\mathrm{av}}=8.4 \cdot \mathrm{kg} / \mathrm{m}^{3}$ (from $0.3 \mathrm{M}$ to $0.15 \mathrm{M}$ at the end) overall mass transfer coefficient $-\mathrm{K}_{\mathrm{o}}$ becomes $8.32 \cdot 10^{-8} \mathrm{~m} / \mathrm{s}$. Mass transfer coefficient for FC consists of two parts: (i) transport from bulk liquid to particle surface (the same case as in pure cryolite) and (ii) transport inside solid carbon matrix. Adequately, $\mathrm{K}_{\mathrm{o}}$ consists of two resistances: resistance of the transport to the surface (in the liquid film around particles) and inside solid particles (resistance in solid). Assuming the replacement of the external resistance by previously calculated value for pure cryolite the internal resistance, inside the particle can be calculated. Results of internal resistance $1 / \mathrm{k}_{\mathrm{s}}=$ $1.2 \cdot 10^{7} \cdot \mathrm{s} / \mathrm{m}$, and external $1 / \mathrm{k}_{1}=6.2 \cdot 10^{5} \cdot \mathrm{s} / \mathrm{m}$ indicates that resistance to diffusion inside solid particles is 19 times higher than in liquid. Such basic information opens possibilities to the development of the SPL treatment process, to find an adequate contacting method and other corresponding technological parameters supported by chemical engineering knowledge.

Solubility diagram Fig. 5 based on Equation (3) and data from Selvaraj ${ }^{21}$ gives the possibility to represent mass balance in the liquid phase. The process starts on the abscissa and ends on the ordinate axis. Different
$\mathrm{NaOH}$ concentrations give larger $(\mathrm{L} / \mathrm{S})_{\min }$ ratios which at 0.6 exceed the solubility curve at the end of a process and should operate at a larger $\mathrm{L} / \mathrm{S}$ ratio than minimal.

Comparable results of the cryolite disintegration are possible to be achieved with FC samples where remaining cryolite content is left in the range between 5\% and 10\% (of whole FC sample) at the process conditions discussed above. These material quality specification frames open two general issues with imposed answers:

1. What is the optimal particle size of the SPL material needed? Answer: main selection criteria should follow application possibilities and corresponding particle size specifications.

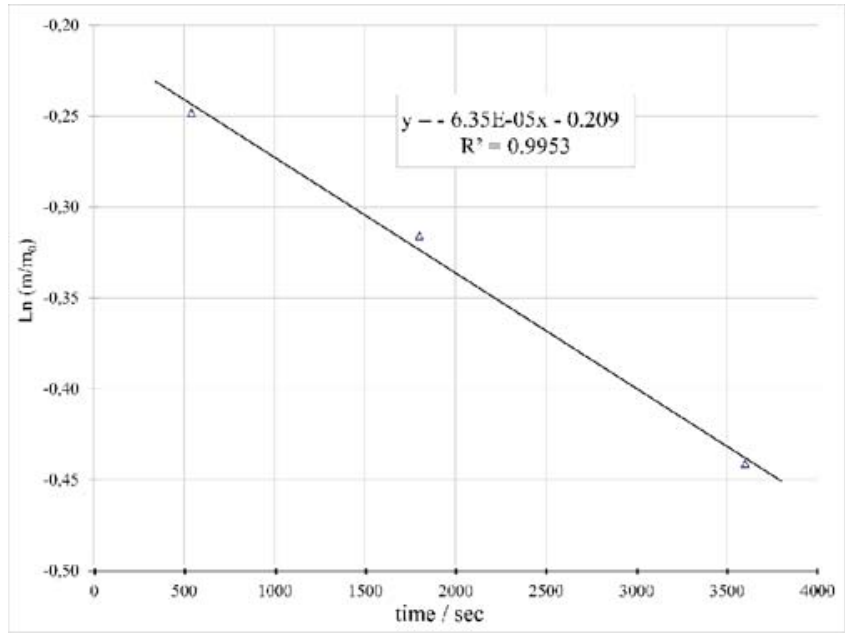

Figure 4. Decomposition kinetics of FC sample calculated by Equation (6) in $0.3 \mathrm{M} \mathrm{NaOH}$ solution and L/S 21 $\mathrm{ml} / \mathrm{g}$ (based on cryolite content) 1.43 times $(L / S)_{\min }$

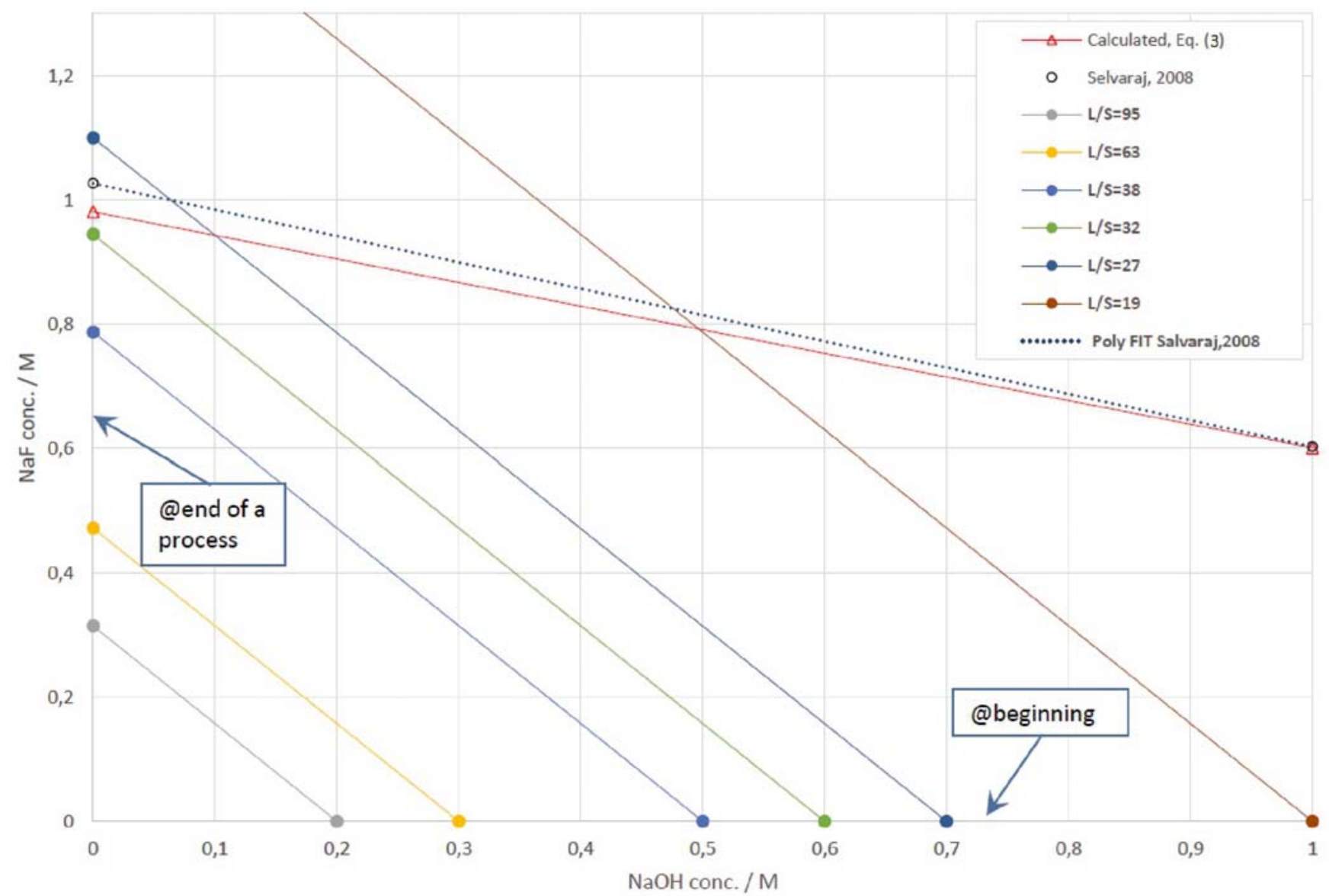

Figure 5. Diagram of $\mathrm{NaF}$ conc. in $\mathrm{NaOH}$ solution presented as liquid phase mass balance diagram with different $(L / S)_{\min }$ ratios at the start and end of a process 
2. Results and evidence support the suggestion that process and economical optimum of final product quality lies in the range of $10 \%>\mathrm{C}_{\text {cyolite }}>5 \%$ and $\mathrm{C}_{\mathrm{fix}} \geq 80 \%$ with no water leachable and toxic components. Response: explore application possibilities of the SPL - FC and $\mathrm{SC}$ material with proposed composition to find related particle size requests.

\section{CONCLUSIONS}

With the revealing of the alkaline cryolite decomposition reaction mechanism and corresponding process kinetics model, a basis for the development of a reactive extraction process of SPL is established. Complex, but valuable waste materials like SPL, need to be prepared processed before entering into a local chain of a circular economy. Complex material also needs a straightforward combination of mechanical and chemical procedures to gain a marketable and environmentally acceptable material as sustainable application.

Reaction mechanism with ligand exchange to complex aluminium ion and the common ion effect on solubility in reactant solution are the key parameters in the first part of the process. The water extraction step eliminates originally presented product $-\mathrm{NaF}$ to enable cryolite decomposition reaction and transport of reactant $\mathrm{NaOH}$ and products, mainly $\mathrm{NaF}$, by diffusion running process into bulk extraction liquid solution. Keeping $\mathrm{NaOH}$ concentrations low between 0.1 to $0.3 \mathrm{M}$, without introducing new ionic species into the reaction and extraction system and operation at room temperatures simplifies the process and contributes to its economics. This $\mathrm{NaOH}$ concentration range is also within the range proposed in the patent applied to the Slovenian Intellectual Property Office (SIPO) ${ }^{25}$.

The experiments with pure cryolite allowed the quantification of the mass transfer coefficients related to the $\mathrm{NaOH}$ transfer from the solution to the surface of the cyolite particles. In the case of the SPL material, the cryolite is dispersed inside particles, the mass transfer coefficient of $\mathrm{NaOH}$ also includes its diffusion within the SPL particle.

As the kinetic modeling and measurements give the internal resistance, inside the particle, 19 times larger than the external one (in liquid phase), larger resistance governs the time of the overall process of decomposition and extraction. Such process circumstances impose careful selection of the technology, process and equipment adequately, according to the primary recognition learned that diffusion governs the process.

Composition of the final product with high carbon content $-\mathrm{C}_{\mathrm{fix}}>80 \%$, some amount of $\mathrm{CaF}_{2}$ and a small part of remaining cryolite with alumina and silicates direct application possibilities toward metallurgy, cement, mineral wool production and others. Particle size mostly depends on the application and needs to be adapted thoughtfully.

\section{ACKNOWLEDGMENTS}

The authors gratefully acknowledge support from the University of Maribor, Faculty of mechanical engineering for managing to unite interdisciplinary professions. To a Talum d. d. (JSC) Company Kidričevo Slovenia for providing the SPL samples and for financial support for analytics, especially to Mr. A. Sibila at the time director of strategic development for his understanding of the problem. The authors would like to acknowledge prof. N. Samec for support at the initiation of the SPL research in the $\mathrm{PhD}$ program and to assistant professor B. Kozlevčar for his consultancy on ligands. The authors acknowledge the financial support from the Slovenian Research Agency program P2-0346 and partly support of the SPL-CYCLE project under PA 17141 from the European Institute of Innovation and Technology (EIT) a body of European Union's Horizon 2020 research and innovation programme.

\section{NOMENCLATURE}

A surface area of cryolite sample $\left(\mathrm{m}^{2}\right)$,

$A_{p} \quad$ surface area of cryolite particle $\left(\mathrm{m}^{2}\right)$,

$\mathrm{C}$ number of Components,

$\mathrm{C}_{\text {cryolite }}$ cryolite content (\%),

$\mathrm{C}_{\text {fix }} \quad$ fixed carbon content (\%),

D diffusivity $\left(\mathrm{m}^{2} \cdot \mathrm{s}^{-1}\right)$,

$\mathrm{d}_{50} \quad$ average particle diameter $(\mu \mathrm{m})$,

$\mathrm{F}$ number of degrees of Freedom,

FC First Cut,

HTM Hazardous Toxic Materials,

ICCD ICCD type of camera,

J mass flux through the stagnant film $\left(\mathrm{kg} \cdot \mathrm{m}^{-2} \mathrm{~s}^{-1}\right)$,

$\mathrm{K}$ proportional factor in Eq. $6-K=\frac{3 k_{l} \Delta C}{\rho_{p} r_{p}}\left(\mathrm{~s}^{-1}\right)$ $\left(\mathrm{s}^{-1}\right)$,

$\mathrm{K}_{\mathrm{o}}$

$k_{l} \quad$ individual liquid phase mass transfer coefficient $\left(\mathrm{m} \cdot \mathrm{s}^{-1}\right)$,

$k_{s} \quad$ individual solid mass transfer coefficient $\left(\mathrm{m} \cdot \mathrm{s}^{-1}\right)$,

$\mathrm{K}_{\mathrm{sp}} \quad$ Solubility product constant $\left(\mathrm{mol}^{2} \cdot \mathrm{dm}^{-6}\right)$,

$\mathrm{L} / \mathrm{S} \quad$ Liquid to Solid ratio $\left(\mathrm{ml} \cdot \mathrm{g}^{-1}\right)$,

$(\mathrm{L} / \mathrm{S})_{\min }$ minimum liquid to solid ratio $\left(\mathrm{ml} \cdot \mathrm{g}^{-1}\right)$,

$\mathrm{m}$ mass of cryolite sample $(\mathrm{g})$,

$\mathrm{m}_{0} \quad$ the initial mass of cryolite sample $(\mathrm{g})$,

$\mathrm{n}_{\mathrm{p}} \quad$ number of cryolite particles in cryolite sample

$\mathrm{P}$ number of phases,

$r_{p} \quad$ radius of cryolite particle $(\mu \mathrm{m})$,

SC Second Cut,

SPL Spent Pot Lining,

$\mathrm{t}$ time of cryolite decomposition (s),

$X R D \quad \mathrm{X}$-ray Diffraction, identifies type and

amount of mineral phases in the sample,

$X R F \quad \mathrm{X}$-ray Fluorescence, gives information on elemental composition of sample,

$\delta_{\mathrm{f}} \quad$ thickness of stagnant film around particles $(\mu \mathrm{m})$,

$\rho_{\mathrm{p}} \quad$ density of cryolite $\left(\mathrm{kg} \cdot \mathrm{m}^{-3}\right)$,

$\Delta \mathrm{C} \quad$ concentration gradient $\left(\mathrm{kg} \cdot \mathrm{m}^{-3}\right)$,

$1 / k_{1} \quad$ external resistance in the liquid film around particles $\left(\mathrm{s} \cdot \mathrm{m}^{-1}\right)$,

$1 / \mathrm{k}_{\mathrm{s}} \quad$ internal resistance inside solid particles $\left(\mathrm{s} \cdot \mathrm{m}^{-1}\right)$. 


\section{LITERATURE CITED}

1. Holywell, G. \& Breault, R. (2013). An overview of useful methods to treat, recover, or recycle spent potlining, JOM. 65, 1441-1451. DOI: 10.1007/s11837-013-0769-y.

2. Pawlek, R.P. (2012). Spent Potlining: An Update, in: Light Met., 2012. DOI: 10.1002/9781118359259.ch227.

3. Chauke, L. \& Garbers-Craig, A.M. (2013). Reactivity between carbon cathode materials and electrolyte based on industrial and laboratory data, Carbon N. Y. 58, 40-45. DOI: 10.1016/j.carbon.2013.02.023.

4. Hop, J.G., Støre, A., Foosnæs, T. \& Øye, H.A. (2004). Chemical and physical changes of cathode carbon by aluminium electrolysis, VII Int. Conf. Molten Slags Fuxes Salts. 775-782. DOI: $10.1179 / 037195505 \times 63376$.

5. Østrem, Ø. (2013). Cathode wear in Hall-Héroult cells, Thesis for the degree of $\mathrm{PhD}$, Norwegian University of Science and Technology, Faculty of Natural Sciences and Technology, Department of Materials Science and Engineering.

6. Silveira, B.I., Dantas, A.E., Blasquez, J.E. \& Santos, R.K.P. (2002). Characterization of inorganic fraction of spent potliners: Evaluation of the cyanides and fluorides content, J. Hazard. Mater. 89, 177-183. DOI: 10.1016/S0304-3894(01)00303-X.

7. Mikša, D., Homšak, M. \& Samec, N. (2003). Spent potlining utilisation possibilities, Waste Manag. Res. 21, 467-473. DOI: $10.1177 / 0734242 X 0302100509$.

8. Tropenauer, B., Klinar, D., Samec, N. \& Golob, J. 2018. Circular economy model of cathode waste processing. DOI: 10.18690/978-961-286-211-4.8.

9. O'Neil, M.J. (ed.), (2001). The Merck Index - An Encyclopedia of Chemicals, Drugs, and Biologicals. 13th Edition, Whitehouse Station, NJ: Merck and Co., Inc., p. 456.

10. Cenčič, M., Kobal, I. \& Golob, J. (1998). Thermal Hydrolysis of Cyanides in Spent Pot Lining of Aluminium Electrolysis, Chem. Eng. Technol. 21, 523-532. DOI: 10.1002/(SICI)15214125(199806)21:6<523::AID-CEAT523>3.0.CO;2-P.

11. Ntuk, U., Tait, S. White, E.T. \& Steel, K.M. (2015). The precipitation and solubility of aluminium hydroxyfluoride hydrate between 30 and $70^{\circ} \mathrm{C}$. Hydrometallurgy, 155, 79-87. DOI: 10.1016/j.hydromet.2015.04.010.

12. Schönfelder, I., Gock, E. Tochtrop, E. \& Schmidt Rieder, E. 2015. Recycling von Elektrolyseausbruch (SPL) aus der Primäraluminiumgewinnung, (n.d.). http://www.vivis.de/ phocadownload/Download/2015 rur/2015_RuR 385-404_Gock. pdf (accessed June 15, 2018).

13. Zhao, L.C. 2001. Comprehensive recovery of waste linings of aluminium electrolysers, CN patent 1,320,491 (Appl. date 28 February 2001). https://patents.google.com/patent/ CN1320491A/en.
14. Shi, Z., Li, W. Hu, X., Ren, B., Gao, B. \& Wang, Z. (2012). Recovery of carbon and cryolite from spent pot lining of aluminium reduction cells by chemical leaching, Trans. Nonferrous Met. Soc. China, 22, 222-227. DOI:10.1016/S10036326(11)61164-3.

15. Kasireddy, V., Bernuer, J.L. \& Kimmerle, F.M. (2003). Recycling of spent pot linings, US patent No.: US 6,596,252 B2, Date of Patent: Jul. 22, 2003.

16. Lisbona, D.F. \& Steel, K.M. (2008). Recovery of fluoride values from spent pot-lining: Precipitation of an aluminium hydroxyfluoride hydrate product, Sep. Purif. Technol. 61(2), 182-192. DOI: 10.1016/j.seppur.2007.10.012.

17. NIOSH - The National Institute for Occupational Safety and Health. 2016, Solubility of Cryolite, (2016). access on 10. Jun 2018 https://www.cdc.gov/niosh/npg/npgd0559.html.

18. Staffan Sjoeberg, Chemical Specification in Aqueous $\mathrm{Al}^{3+}-\mathrm{F}^{-}-\mathrm{OH}^{-}$Systems of relevance to Natural Waters and Body Fluids: The dissolution of AlF3 and Na3AlF6 (cryolite). Department of Inorganic Chemistry, Umeå University, Sweden. Unpublished report for Toxicon AB, (2002). (Committee for Risk Assessment RAC Annex 1 Background Document to the Opinion proposing harmonised classification and labelling at Community level of Trisodium hexafluoroaluminate (cryolite), natural and synthetic; 2010).

19. Averill, B. \& Eldredge, P. (2016). General Chemistry: Principles, Patterns, and Applications 1.0 |Flat World Education, Flat World Educ.

20. Reynolds, J.G. \& Belsher, J.D. (2017). A Review of Sodium Fluoride Solubility in Water. J. Chem. Eng. 62(6), 1743-1748. DOI: 10.1021/acs.jced.7b00089.

21. Selvaraj, D., Toghiani, R.K. \& Lindner, J.S. (2017). Solubility in the $\mathrm{Na}+\mathrm{F}+\mathrm{NO}_{3}$ and $\mathrm{Na}+\mathrm{PO}_{4}+\mathrm{NO}_{3}$ Systems in Water and in Sodium Hydroxide Solutions. J. Chem. Eng. 53(6), 1250-1255.DOI:10.1021/je700597m.

22. Weber, C.F., Beahm, E.C., Lee, D.D. \& Watson, J.S. (2000). A Solubility Model for Aqueous Solutions Containing Sodium, Fluoride, and Phosphate Ions, Ind. Eng. Chem. Res. 39(2), 518-526. DOI: 10.1021/ie9904571.

23. Xiping, C. \& Wangxing, L. (2007). Research on crushing character of spent cathode, in: TMS Light Materials.

24. Tropenauer, B., Klinar, D., Samec, N., Golob, J. \& Kortnik, J. (2019). Sustainable waste-treatment procedure for the spent potlining (SPL) from aluminium production. Mater. Tehnol. 53(2), 277-284. DOI: 10.17222/mit.2018.147.

25. Patent application No.: P-201900265, Slovenian Intellectual Property Office (SIPO), (January 6. 2020). 